\title{
Flow-through Chemiluminescence Sensor Using Immobilized Histamine Oxidase from Arthrobacter crystallopoietes KAIT-B- 007 and Peroxidase for Selective Determination of Histamine
}

\author{
Yoshinori Sekiguchi,* Aya NishiKawa,* Hiroko Makita,** Akira Yamamura,* \\ Kunio МАтsUмOTо, ${ }^{* *}$ and Nobutoshi KIBA**** \\ *Department of Applied Chemistry, Faculty of Engineering, Kanagawa Institute of Technology, \\ Shimo-ogino 1030, Atsugi 243-0292, Japan \\ ** Department of Biochemistry, Faculty of Engineering, Yokohama National University, \\ Tokiwadai 79-1, Hodogaya, Yokohama 240-0067, Japan \\ ***Department of Applied Chemistry and Biotechnology, Faculty of Engineering, Yamanashi University, \\ Takeda 4-3-11, Kofu 400-8511, Japan
}

\begin{abstract}
A flow sensor with immobilized oxidases is proposed for the determination of histamine in fish meat. Chemiluminometric measurement of histamine was based on the luminol reaction with hydrogen peroxide produced by immobilized histamine oxidase (EC 1.4.3.-.) and peroxidase (EC 1.11.1.7.) within a flow cell. Histamine oxidase was found in cells of Arthrobacter crystallopoietes KAIT-B-007 isolated from soil. The oxidase and peroxidase were coimmobilized covalently on tresylated hydrophilic vinyl polymer beads and packed into transparent PTFE; the tubing was used as the flow cell. One assay for histamine was done at intervals of 2 min without carryover. The calibration curve for histamine was linear from $0.1 \mu \mathrm{M}$ to $50 \mu \mathrm{M}$. The response was reproducible within $1.25 \%$ of the relative standard deviation for 115-replicate injections of $50 \mu \mathrm{M}$ histamine. The sensor system was applied to the determination of histamine in fish meat extracts.
\end{abstract}

(Received July 13, 2001; Accepted August 6, 2001)

Histamine (1H-imidazole-4-ethanamine, Him) is well known as a putrefactive amine, which causes an allergy-like food poisoning (Him poisoning). ${ }^{1}$ Though Him is not present in fresh fish, it is formed when the fish was contaminated with the microorganisms which has a strong histidine decarboxylase [EC 4.1.1.22.] activity; the histamine is formed by decarboxylation from L-histidine. Therefore, Him in fish meat extracts is a marker of fish freshness. Since Japanese usually eat raw fish, merchants are required to give particular care to freshness and quality of fish. The determination of Him in fish meat is important for the evaluation of the degree of the freshness and the prevention of food poisoning incidents.

Fluorometry ${ }^{2}$ and high performance liquid chromatography (HPLC) $)^{3-6}$ have been mainly used for the Him determination, but those methods are deficient in the rapidity and simplicity. The HPLC methods are reliable, but they produce an excessive amount of information that is not required for the purpose and result in high cost per analysis. Enzymatic methods with histamine oxidase (EC 1.4.3.6) have been proposed for a more selective determination of Him. ${ }^{7-10}$ The oxidase catalyzes the oxidative deamination of Him to imidazol acetaldehyde with the simultaneous production of ammonia and hydrogen peroxide; $\mathrm{Him}+\mathrm{H}_{2} \mathrm{O}+\mathrm{O}_{2} \longrightarrow$ imidazole acetaldehyde $+\mathrm{NH}_{3}+\mathrm{H}_{2} \mathrm{O}_{2}$. The formed hydrogen peroxide has been measured electrochemically, ${ }^{7,8} \quad$ colorimetrically ${ }^{9}$ and chemiluminometrically. ${ }^{10}$ The enzyme had low stability.

† To whom correspondence should be addressed.

E-mail: matumoto@chem.kanagawa-it.ac.jp
Recently, we found a new histamine oxidase (EC 1.4.3.-, HOD) having high stability in cells of Arthrobacter crystallopoietes KAIT-B-007 isolated from soil. ${ }^{12}$

This paper describes a single line flow-injection system for the chemiluminometric determination of Him using a flowthrough sensor which was packed with coimmobilized the HOD and peroxidase (POD). HOD and POD were coimmobilized covalently to tresylated hydrophilic vinyl polymer beads and packed in a transparent PTFE [poly(tetrafluoro)ethylene] tubing. The PTFE tubing was used as a flow cell. Enzymatic reactions were performed in a $500 \mu \mathrm{M}$ luminol in CHES buffer $(\mathrm{pH} 10.0)$ in the flow cell; POD catalyzes the chemiluminescence reaction of luminol with hydrogen peroxide, $2 \mathrm{H}_{2} \mathrm{O}_{2}+$ luminol $+\mathrm{OH}^{-} \longrightarrow 3$-aminophthalate $+\mathrm{N}_{2}$ $+3 \mathrm{H}_{2} \mathrm{O}+\mathrm{h} v$. By coupling the enzyme reactions in the flow cell, the second reaction acts as a trapping agent and the equilibrium for the first reaction is displaced in favor of the production. ${ }^{11}$ In this case, POD reaction is the trapping agent. The method was applied to the determination of Him in mackerel meat extracts.

\section{Experimental}

Materials and reagents

HOD (histamine: oxygen oxidoreductase, $0.2 \mathrm{U} / \mathrm{ml}$ ) was produced in our laboratory by fermentation of $A$. crystallopoietes KAIT-B-007. The enzyme was purified from cell-free extracts of KAIT-B-007. Purification of the enzyme 
was performed by a procedure involving ammonium sulfate fractionation, column chromatography on DEAE-Sepharose, Phenyl-Sepharose, and gel filtration with Sephacryl S-200. HOD activity was assayed photometrically by measuring the amount of hydrogen peroxide produced from Him as substrate with 4-aminoantipyrine and POD. The properties of the HOD were as follows: molecular weight, 81000; structure, no subunit; Michaelis constant, $5.1 \times 10^{-4} \mathrm{M}$; inhibitors, hydrazine, $N, N$ diethyldithiocarbamate and 8-hydroxyquinoline, optimum $\mathrm{pH}$, 9.0; optimum temperature, $40-45^{\circ} \mathrm{C} ; \mathrm{pH}$ stability, $\mathrm{pH} 6-9$ $\left(30^{\circ} \mathrm{C}, 1 \mathrm{~h}\right)$; thermal stability, below $70^{\circ} \mathrm{C}(\mathrm{pH} 7.0,10 \mathrm{~min})$. In comparison with the properties of HOD from Arthrobacter globitormis, ${ }^{7-10}$ the HOD used in this study is excellent in thermal stability, and the $\mathrm{pH}$ stability and the optimum $\mathrm{pH}$ value at higher $\mathrm{pH}$; these conditions are favorable for the PODcatalyzed luminol chemiluminescence reaction.

POD (from Arthromyces ramosus, $250 \mathrm{U} / \mathrm{mg}$ ), tresyl chloride (2,2,2-trifluoroehanesulfonyl chloride) and hydrophilic vinyl polymer beads (TSKgel Toyopearl HW-65F, particle size <70 $\mu \mathrm{m})$ were purchased from Suntory (Osaka, Japan), Nacalai Tesque (Kyoto, Japan) and Tosoh (Tokyo, Japan), respectively. Toyopearl beads were sieved to obtain $50 \pm 5 \mu \mathrm{m}$ sieve fraction. Histamine dihydrochloride and 4-aminoantipyrine were purchased from Wako Pure Chemical Industries (Tokyo, Japan). Same transparent PTFE tubing was purchased from Valqua (Tokyo, Japan). All other reagents were of analytical-reagent grade.

A stock solution $(5 \mathrm{mM})$ of luminol (5-amino-2,3-dihydro1,4-phthalazinedione) was prepared by dissolving in $0.1 \mathrm{M}$ CHES ( $N$-cyclohexyl-2-aminoethanesulfonic acid)-NaOH buffer ( $\mathrm{pH} 10.0)$ and diluted ten-fold with the buffer before use.

Standard Him solutions were prepared daily by dissolving Him in the CHES buffer ( $\mathrm{pH} 10.0$ ).

\section{Preparation of coimmobilized enzymes}

HOD and POD were coimmobilized on the Toyopearl beads by the method described previously. ${ }^{13}$ The $0.5 \mathrm{~g}$ of the beads was washed with $50 \mathrm{ml}$ of dry acetone and suspended in $10 \mathrm{ml}$ of dry acetone-pyridine $(1: 1 \mathrm{v} / \mathrm{v})$. With vigorous magnetic stirring, $1 \mathrm{ml}$ of tresyl chloride was dropwise added to the suspension over $5 \mathrm{~min}$. The reaction was continued for $10 \mathrm{~min}$. The beads were washed with $20 \mathrm{ml}$ of acetone and then with 20 $\mathrm{ml}$ of $1 \mathrm{mM}$ hydrochloric acid. The tresylated beads were packed into a transparent PTFE $(40 \mathrm{~cm} \times 1.0 \mathrm{~mm}$ i.d., $1.5 \mathrm{~mm}$ o.d., limiting pressure $50 \mathrm{~kg} / \mathrm{cm}^{2}$ ) by slurry-packing method. Both ends of the tube were closed with ceramic frits (GL Sciences, Tokyo, Japan). The enzyme solution [HOD (10 ml, 2 $\mathrm{U})$ and POD (2 mg, $500 \mathrm{U})$ in $10 \mathrm{ml}$ of $0.1 \mathrm{M}$ phosphate buffer (pH 7.0)] was circulated through the tube at $0.2 \mathrm{ml} \mathrm{min}^{-1}$ for 9 h. The coimmobilized enzymes were washed with $0.1 \mathrm{M}$ Tris- $\mathrm{HCl}$ buffer ( $\mathrm{pH} \mathrm{8.0)}$ to saturate the free linking sites. Then the tube was coiled spirally and used as the flow cell.

The result evaluated by measuring the decrease in amount of protein in the enzyme solution after the immobilization process, the HOD was immobilized with $95 \%$ yield.

\section{Flow system and procedure}

The FI system used in this study is outlined in Fig. 1. The luminol solution $(500 \mu \mathrm{M})$ was pumped by a Hitachi L-6000

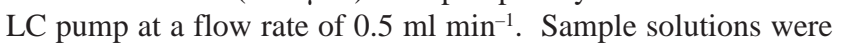
injected through a Sanuki SVM-6M six-way valve equipped with a $10 \mu \mathrm{l}$ loop. The chemiluminescence was measured at room temperature $\left(20 \pm 2^{\circ} \mathrm{C}\right)$ with a Soma S-3400 luminometer, connected to TOA FBR251A recorder.

The flow cell was washed with $0.1 \mathrm{M}$ phosphate buffer $(\mathrm{pH}$

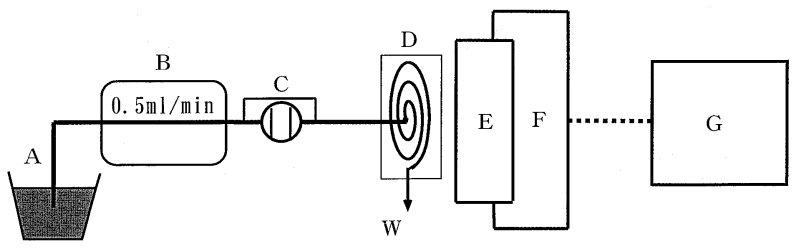

Fig. 1 Flow-injection set-up for the chemiluminometric determination of histamine: $\mathrm{A}, 500 \mu \mathrm{M}$ luminol in $0.1 \mathrm{M}$ CHES$\mathrm{NaOH}$ buffer (pH 10.0); B, pump; C, six way valve with a $10 \mu 1$ loop; $\mathrm{D}$, flow cell (40 cm length, $1.5 \mathrm{~mm}$ o.d., $1.0 \mathrm{~mm}$ i.d.) packed with coimmobilized histamine oxidase/peroxidase; E, photomultiplier tube; F, luminometer; G, recorder; W, waste.

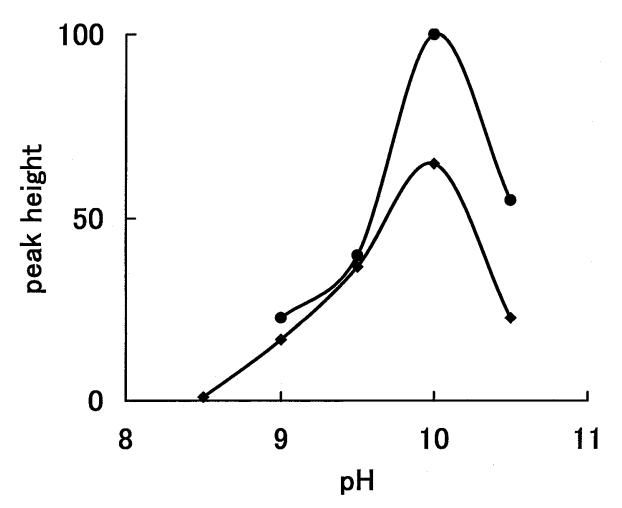

Fig. 2 The effect of $\mathrm{pH}$ on the chemiluminescence intensity. The intensity was measured using the system shown in Fig. 1. •: CHES$\mathrm{NaOH}$ buffer, $\bullet$ : carbonate buffer.

7.0) and then stored in a refrigerator $\left(4^{\circ} \mathrm{C}\right)$ when not in use.

The present method was compared with HPLC. ${ }^{3}$ Fresh mackerel meat was kept for 3 days at $10^{\circ} \mathrm{C}$ in a refrigerator. The meat $(5 \mathrm{~g})$ was suspended in $0.1 \mathrm{M}$ phosphate buffer $(\mathrm{pH}$ 7.0) $(25 \mathrm{ml})$, milled mechanically and centrifuged $(13000 \mathrm{~g})$ for $15 \mathrm{~min}$ at room temperature. The supernatant solution was heated at $90^{\circ} \mathrm{C}$ for $5 \mathrm{~min}$, centrifuged and filtered with a membrane filter $(0.2 \mu \mathrm{m})$. The filtrate was diluted with water to $25 \mathrm{ml}$. The solution was further diluted with the CHES buffer ( $\mathrm{pH} 10.0)$; measurements were made on solutions ranging in concentration from 0.1 to $50 \mu \mathrm{M}$. Each solution $(10 \mu \mathrm{l})$ was injected via the valve.

\section{Results and Discussion}

\section{Optimization of the flow-through sensor}

The activities of HOD and POD in the enzyme solution varied from 2 and $250 \mathrm{U}$ to 2 and $750 \mathrm{U}$. The resulting coimmobilized enzymes were packed into the flow cell and $50 \mu \mathrm{M}$ Him was injected to the FI system shown in Fig. 1. The peak heights increased with increasing the amounts of POD; above $400 \mathrm{U}$ $(1.6 \mathrm{mg}$ ) they were almost constant. An enzyme solution containing $2 \mathrm{U}$ of HOD and $500 \mathrm{U}$ of POD (2 mg) was used for preparation of coimmobilized enzymes.

The effect of $\mathrm{pH}$ on the chemiluminescence intensity was examined in the $\mathrm{pH}$ range from 8.5 to 10.5 using two kinds of buffers (CHES-NaOH buffer and carbonate buffer) by injecting $10 \mu \mathrm{l}$ of $50 \mu \mathrm{M} \mathrm{Him}$. The maximum sensitivity was found to be at about 10.0 with 0.1 M CHES-NaOH buffer, as shown in Fig. 2. At $\mathrm{pH} 10.0$, the activity in CHES-NaOH buffer is 1.4 times 
Table 1 Substrate specificity of coimmobilized HOD/POD (The relative activities for various substrates $(50 \mu \mathrm{M})$ were measured using the system shown in Fig. 1.)

\begin{tabular}{lc}
\hline \multicolumn{1}{c}{ Substrate } & Relative peak height, $\%$ \\
\hline Histamine & 100 \\
Methylamine & 0 \\
Ethylamine & 0 \\
Propylamine & 7 \\
Butylamine & 22 \\
Phenethylamine & 32 \\
Hexylamine & 41 \\
Isobutylamine & 0 \\
2-Aminoethanol & 0 \\
Benzylamine & 0 \\
Tyramine & 36 \\
Dopamine & 51 \\
Tryptamine & 15 \\
Agmatine & 4 \\
Putrescine & 0 \\
Cadaverine & 0 \\
Spermine & 0 \\
Spermidine & 0 \\
\hline
\end{tabular}

that in carbonate buffer. In CHES-NaOH buffer POD was not activated, but HOD was activated; this was confirmed by injecting hydrogen peroxide in the place of Him. The influence of luminol concentration on the intensity was examined from $200 \mu \mathrm{M}$ to $500 \mu \mathrm{M}$ in $0.1 \mathrm{M}$ CHES-NaOH buffer (pH 10.0). The peak height was constant from 400 to $500 \mu \mathrm{M}$. Above 500 $\mu \mathrm{M}$ the peak heights decreased because the presence of a large quantity of luminol quenches the luminescence. A $500 \mu \mathrm{M}$ luminol solution in $0.1 \mathrm{M}$ CHES-NaOH buffer ( $\mathrm{pH} 10.0$ ) was used in this study. The peak height was measured by changing the flow rate of the luminol solution from 0.2 to $1.0 \mathrm{ml} \mathrm{min}{ }^{-1}$. The maximum was found for about $0.5 \mathrm{ml} \mathrm{min}^{-1}$. At below 0.5 $\mathrm{ml} \mathrm{min}^{-1}$, the peak height increased with increasing the flow rate. An increase in peak height was due to sharpening the peak with increasing flow rate because the peak areas decreased with increasing the flow rate; the reactions are dependent on the flow rate even at lower flow rates. Above $0.5 \mathrm{ml} \mathrm{min}{ }^{-1}$ both the peak heights and the areas decreased with increasing the flow rate. At a flow rate of $0.5 \mathrm{ml} \mathrm{min}{ }^{-1}$, maximum sample throughput was $30 \mathrm{~h}^{-1}$ without carryover.

\section{Substrate specificity of coimmobilized enzymes}

The substrate specificity of coimmobilized HOD/POD was examined using the various monoamines and diamines listed in Table 1, in the system shown in Fig. 1. The coimmobilized enzymes were inactive toward diamines which are putrefaction products, such as putrescine, cadaverine, spermine and spermidine. The relative activities for each amine were compared with those obtained with HOD in solution with spectrophtometric method. The data also are shown in Table 1. By the immobilization, the specificity was lowered; this is not yet explicable.

\section{Calibration curve}

A calibration curve was prepared using $10 \mu \mathrm{l}$ of standard Him solutions. The plot of chemiluminescence intensity (peak height) against Him concentration was linear from $0.1 \mu \mathrm{M}$ to 50 $\mu \mathrm{M}$. The least-squares calibration equation for Him was $Y=$ $302.18 X-0.01$, where $Y$ is the peak height $(\mathrm{mm})$ and $X$ the concentration $(\mu \mathrm{M})$, with linear correlation coefficient of $r=$
Table 2 Recoveries of histamine added to mackerel meat extracts

\begin{tabular}{cccc}
\hline \multirow{2}{*}{ Sample } & \multicolumn{2}{c}{ Amount of $\mathrm{Him} / \mu \mathrm{M}$} & \multirow{2}{*}{ Mean recovery, \% $(n=5)$} \\
\cline { 2 - 3 } & Added & Found & \\
\hline \multirow{2}{*}{ A } & - & 54.1 & - \\
& 10.0 & 63.8 & 97.0 \\
& 20.0 & 73.1 & 95.0 \\
B & - & 161 & - \\
& 10.0 & 171 & 100 \\
& 20.0 & 179 & 95.0 \\
C & - & 470 & - \\
& 10.0 & 480 & 100 \\
& 20.0 & 489 & 95.0 \\
\hline
\end{tabular}

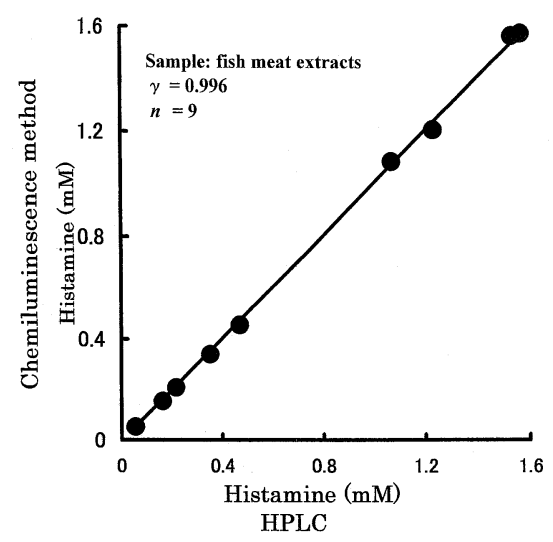

Fig. 3 The comparison between chemiluminometric method and HPLC for the assay of histamine in mackerel meat extracts.

0.9998 (10 data points). The detection limit (signal-to-noise = 3) was $0.08 \mu \mathrm{M}$.

The conversion efficiency of the sensor for HOD reaction was $15.5 \%$ immediately just after the preparation of the sensor; the efficiency was measured by using $\mathrm{H}_{2} \mathrm{O}_{2}$. After 115 replicate injections of $50 \mu \mathrm{M}$ Him for $4 \mathrm{~h}$, no significant signal decrease could be measured and the relative standard deviation (RSD) was $1.25 \%$. After 150 replicate injections of $50 \mu \mathrm{M}$ Him for 3 days, the sensor was stored in a refrigerator $\left(4^{\circ} \mathrm{C}\right)$. After 30 days the efficiency was $14.7 \%$.

\section{Application}

The sensor system shown in Fig. 1 was applied to the determination of Him in mackerel meat extracts.

\section{Recovery}

Mackerel meat extracts of known Him concentrations which were determined by HPLC $^{3}$ was supplemented with standard solutions of Him. The recoveries were in the range $95-100 \%$ as shown in Table 2.

\section{Comparison}

Nine mackerel meat extracts were used as samples in this study. The results were compared with those obtained by HPLC. ${ }^{3}$ The results are shown in Fig. 3. The calculated coefficient and the regression equation were 0.996 and $Y=$ $0.989 X+0.011$, respectively 


\section{Conclusion}

HOD from A. crystallopoietes KAIT-B-007 was able to immobilize covalently on tresylated Toyopearl beads. Chemiluminometric flow-through sensor for the assay of Him can be prepared on the basis of coimmobilized HOD and POD. HOD used in this study was the thermophilic enzyme (heating at $70^{\circ} \mathrm{C}$ for 10 min caused little loss of the activity). The sensor was stable enough to permit the measurement of 150 samples for 3 days and on storage at $4^{\circ} \mathrm{C}$ it was stable for 30 days. This sensor system is applicable to quantification of Him in fish meat extracts.

In this method, tedious pretreatment of fish samples was still needed for accurate and precise determination of Him. If the sensitivity of the enzyme sensor is sufficient to detect a trace amount of Him in highly diluted fish extracts, the problems would be easily solved by dilution. The sensitivity of the sensor can be enhanced by using HOD having higher specific activity. Now, we try to prepare the higher active HOD from Escherichia coli transformant.

\section{Acknowledgements}

This work was supported partly by a Grant-in-Aid for Scientific Research (No. 10650795) from the Ministry of Education, Science, Sports and Culture of Japan.

\section{References}

1. S. L. Taylor and S. S. Sumner, "Seafood Quality Determination", 1986, Elesevier Science Publishers B. V., Amsterdam, 235.

2. W. F. Staruszkiewicz, J. Assoc. Off. Anal. Chem., 1977, 60, 1125.

3. H. Yanaka and M. Matsumoto, J. Food Hyg. Soc. Jpn., 1989, 30, 397.

4. F. Nomura, M. Ohashi, M. Otsuka, O. Adachi, and N. Arakawa, J. Food Hyg. Soc. Jpn., 1996, 37, 109.

5. D. Beil, H. Kinder, A. Paschke, H. Steinhart, D. Vieluf, H. Behrendt, and J. Ring, J. Chromatogr. Sci., 1998, 36, 284.

6. F. Antolini, S. Franciosini, A. Floridi, and A. Floridi, Ital. J. Food Sci., 1999, 11, 335.

7. M. Ohashi, F. Nomura, M. Suzuki, M. Otsuka, O. Adachi, and N. Arakawa, J. Food Sci., 1994, 59, 519.

8. M. Niculescu, I. Frebort, P. Pec, P. Galuszka, B. Mattiasson, and E. Csoregi, Electroanalysis, 2000, 12, 369.

9. T. Kawabata, Y. Uchida, and T. Akano, Bull. Jap. Soc. Sci. Fish, 1960, 26, 1183.

10. M. K. Alam, M. Sasaki, T. Watanabe, and K. Maeyama, Anal. Biochem., 1995, 229, 26.

11. L. J. Blum, S. M. Gautier, A. Berger, P. E. Michel, and P. R. Coulet, Sens. Actuators, B, 1995, 29, 1.

12. Y. Sekiguchi, H. Makita, and K. Matsumoto, Annual Meeting 2000, The Society for Bioscience and Bioengineering, Japan, 2000, 208.

13. N. Kiba, K. Suzuki, T. Miwa, M. Tachibana, H. Koizumi, and K. Tani, Anal. Sci., 2000, 16, 1203. 